\title{
Thermodynamics-based indicators for environmental management and sustainability policies
}

\author{
F. M. Pulselli, S. Borsa, N. Marchettini \& V. Niccolucci \\ Ecodynamics Group - Department of Chemistry, University of Siena, \\ Italy
}

\begin{abstract}
Human activity is deeply funded on the availability of natural resources. They are mostly provided for free by the environment and often neglected by traditional accounting systems since it is difficult to express their contribution or their physical weight in monetary unit, more familiar to most people. Inventorying all the flows of energy and matter that feed a territorial system and giving them a non-market value plays an important role in the field of natural resources management, sustainability policies and territorial planning. A physical based environmental accounting method is implemented in order to evaluate all the resources used within the area on a common basis, beyond the economic scheme, which allows a deeper knowledge of the system. The tool is emergy evaluation, a thermodynamics-based approach, introduced by Howard T. Odum during the 1980s. The use of emergy enables one to calculate some sustainability indicators (such as Environmental Loading Ratio, Emergy per Person, Empower Density, Emergy Investment Ratio), and is able to give a systemic and holistic picture of the system from an environmental point of view. The paper presents a sustainability assessment at regional level by monitoring the use of resources and the results of the analysis could be used to design different development models and scenarios with several implications for the administrative activity. The results orient environmental management solutions for territorial planning and sustainable policies.
\end{abstract}

Keywords: territorial planning, resource management, emergy evaluation; indicators. 


\section{Introduction}

The evaluation of energy and material flows supporting a territorial system can be used to describe the rate of exploitation of the available resources and design environmental management strategies.

This paper presents the results of the emergy evaluation (EME) of an area, namely the Province of Ancona, Italy. The aim of the study is to show a comprehensive assessment of the environmental sustainability of the territorial system as a whole by means of the analysis of emergy flows and indicators. In this way, a "check-up" of the system is provided in order to know the level of environmental stress and the degree of compatibility between human activities and natural cycles, and highlight the environmental criticalities induced on local ecosystems. The results of the analysis can be a valid tool to measure the environmental support to the local inhabitants' lifestyle and the efficiency in the use of energy and matter under a sustainability viewpoint. In fact, in order to implement a correct environmental management programme, before any "sustainability therapy", it is necessary to implement a "sustainability diagnosis" on the basis of a deep objective analysis of the environmental platform which human activities are based upon. Currently, the lack of suitable diagnostic instruments may be revealed when a policy towards sustainable development is programmed [1]. In this sense, emergy evaluation can be included in the class of systemic environmental accounting methods, together with Material Flow Accounting [2], Environmental Space [3], Exergy Analysis [4, 5], Ecological Footprint $[6,7]$.

\section{Methods: emergy evaluation}

During the 80's, an ecologist, Howard T. Odum, proposed a thermodynamic description of the energy transformations within the biosphere. It is a flexible and intuitive idea that is based on the concept of emergy. Odum sought to show quantitatively the fact that, in order to obtain a certain quantity of energy of one kind, a larger quantity of energy of lower quality is necessary [8-10]. To produce high quality energy, for example electricity, we need a lot of low quality energy, for example chemical energy in fuels. Supposing that solar energy is the basic energy of all natural processes and energy transformations, he defined emergy as the quantity of solar energy necessary (directly or indirectly) to obtain a product or energy flow in a given process. Emergy could be defined as the memory of all the solar energy consumed during the process. Hence, the greater the emergy flow necessary to support a process, the greater its environmental cost. Any system needs several inputs to survive and the emergy of all inputs is calculated in terms of solar emergy joules (sej) by means of suitable transformities. Transformity is the factor to convert each kind of energy in terms of emergy (i.e. equivalent solar energy) and its unit is sej $\mathrm{J}^{-1}$ (when expressed in other units, e.g. $\mathrm{sej} /$ gram or sej/litre, the factor is called specific emergy). It represents all past environmental work necessary to obtain one unit of a given resource. 


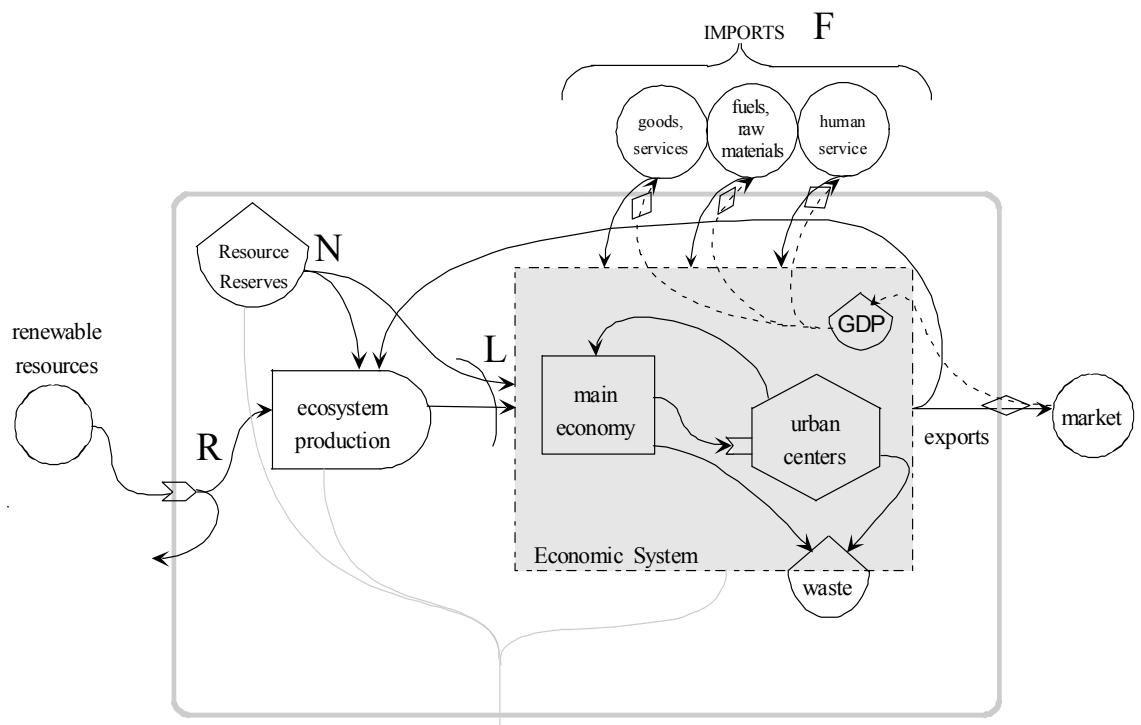

Figure 1: Basic emergy diagram for a typical territorial system with its major resources inputs.

Once all the resources supporting a system have been defined, they can be classified into categories. As showed in Figure 1, the total emergy of a territorial system is divided into renewable $(\mathrm{R})$ non-renewable $(\mathrm{N})$ and imported from outside inputs $(\mathrm{F})$. Renewable and non-renewable flows, $(\mathrm{R})$ and $(\mathrm{N})$, are locally available and derive directly from the environment; the imported flows ( $F$ feedback flows) are come from the market, outside the system.

The emergy use (total emergy flow) of a system is given by the sum of all its emergy-based inputs, renewable non renewable and purchased from other ecosystems, calculated in sej $\mathrm{yr}^{-1}$. Hence: $\mathrm{EM}=\mathrm{R}+\mathrm{N}+\mathrm{F}$.

After calculating and analysing the total emergy supporting a process or a system, some indicators can be obtained by putting into relation the different categories of inputs.

The environmental loading ratio (ELR) is the ratio of non-renewable indigenous emergy and imported emergy to renewable environmental emergy. This indicator represents the unbalance between non-renewable and renewable resources and constitutes a proxy of the environmental stress. Formally: ELR = $(\mathrm{N}+\mathrm{F}) / \mathrm{R}$.

The emergy yield ratio (EYR) is the total emergy supporting the system divided by the emergy of the inputs F, coming from the economic sector (i.e. not provided for free by the environment). A high value of the EYR indicates whether a process can compete in supplying a primary emergy source for an economy. Formally: $E Y R=(R+N+F) / F$. 
The Emergy Investment Ratio (EIR) is the emergy of the inputs from the economic sector (i.e. not provided for free by the environment) divided by all local emergy both renewable and non-renewable. A high value of this indicator represents fragility of the system due to the high dependence on other ecosystems or economic systems out of control. Formally: EIR $=\mathrm{F} /(\mathrm{R}+\mathrm{N})$.

The areal empower density (ED), the emergy flow per unit area, is a measure of spatial concentration of emergy flow within a process or system. In Western countries, the high value of ED suggests that land is a limiting factor for future development. It is expressed in sej $\mathrm{m}^{-2} \mathrm{yr}^{-1}$. Formally: $\mathrm{ED}=(\mathrm{R}+\mathrm{N}+\mathrm{F}) /$ area.

The emergy per person (EpP) is given by the ratio of total emergy supporting a region to the population. It represents the contribution to unsustainability of each inhabitant, depending on the type of resources that are used up (R, N or F). Its unit is sej inhab. ${ }^{-1} \mathrm{yr}^{-1}$. Formally: $\mathrm{EpP}=(\mathrm{R}+\mathrm{N}+\mathrm{F}) /$ population.

Emergy evaluation gives information about actions and policies with respect to sustainability beyond the boundaries of market [see, for example, 11-14]. The set of emergy-based indicators is proposed to evaluate different scenarios and policies comparing emergy inputs, efficiency, correct use of local resources and their degree of renewability. It also describes the development of a region on the basis of the geo-localization of the flows, diversifying the areas according to the intensity of these flows.

\section{Case study}

Ancona is the main Province of the Marche Region. It is located in the centreeast of Italy in front of the Adriatic Sea. It covers an area of $1,940 \mathrm{~km}^{2}$ (see Figure 2).

Its territory is mainly hilly (66\%) and mountain $(34 \%)$. It has a high population density $\left(229\right.$ inhab. $\left.\mathrm{km}^{-2}\right)$ that is higher than the Italian average density (191 inhab. $\mathrm{km}^{-2}$ ). In particular the coastal areas along the Adriatic Sea

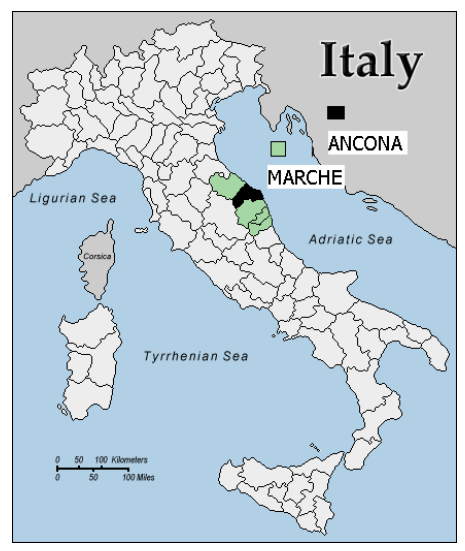

Figure 2: $\quad$ Map of Regione Marche and the Province of Ancona. 
are the most populated and industrialized. Ancona is a dynamic Italian Province. Its economy is based on heavy manufacturing industry and services. Four districts, with different socio-demographic features, within the Province were distinguished and studied separately. The "Comunità Montana Alta Valle dell'Esino" (38\% of the total area) has a low population density, paper industries and agriculture. The district "Media Valle dell'Esino" is located in the centre of the Province and is the smallest one. The other two districts, "Valle del Misa" and "Osimo-Ancona-Falconara" (OAF), are located along the seacoast with a high population density and dynamic centres of services and tourism.

\section{Results and discussion}

Statistical data was collected in order to quantify the resources that are necessary to supply the area of the Province of Ancona. Inputs to the system were given in energy and mass units (see Table 1 and 2) and transformed into equivalent solar emergy joules through suitable transformities. Results (emergy flows and indices) are summarized in Table 3.

As shown in table 3, the total emergy used is $3.50 \times 10^{22}$ sej $\mathrm{yr}^{-1}$. The analysis of flow-categories shows that the system is mainly supported by non renewable resources $(\mathrm{N}+\mathrm{F}=99 \%)$ with only $1 \%$ of renewables $(\mathrm{R})$. The emergy of import (F) is about $86 \%$, divided into imported energy (9\%) and purchased goods and services (77\%). The non renewable local resources $(\mathrm{N})$ account for $13 \%$ and are mainly derived from materials extracted, in particular sand and gravel.

Results therefore show clearly that the regional system acts as a transformer of imported goods and services more than a consumer of local resources.

Table 1: Local inputs and energy use in the territorial system (expressed in energy or mass units); [*See Appendix for references of transformities].

\begin{tabular}{|c|c|c|c|c|c|c|c|c|}
\hline & Unit & $\begin{array}{c}\text { Province of } \\
\text { Ancona }\end{array}$ & $\begin{array}{l}\text { Ancona-Osimo- } \\
\text { Falconara } \\
\text { (AOF) }\end{array}$ & $\begin{array}{c}\text { Bassa Valle } \\
\text { del Misa }\end{array}$ & $\begin{array}{l}\text { Media Valle } \\
\text { dell'Esino }\end{array}$ & $\begin{array}{c}\text { Comunità } \\
\text { Montana Alta } \\
\text { Valle dell'Esino }\end{array}$ & $\begin{array}{l}\text { Transformities } \\
\left(\text { sej unit }^{-1}\right)\end{array}$ & Ref.* \\
\hline \multicolumn{9}{|c|}{ LOCAL RENEWABLE RESOURCES (R) } \\
\hline 1 Sunlight & $\mathrm{J}$ & $7.39 \mathrm{E}+18$ & $2.10 \mathrm{E}+18$ & $1.26 \mathrm{E}+18$ & $1.21 \mathrm{E}+18$ & $2,82 \mathrm{E}+18$ & $1.00 \mathrm{E}+00$ & $a$ \\
\hline 2 Rain & $\mathrm{g}$ & $1.96 \mathrm{E}+15$ & $5.22 \mathrm{E}+14$ & $3.33 \mathrm{E}+14$ & $3.15 \mathrm{E}+14$ & $8,65 \mathrm{E}+14$ & $1.45 \mathrm{E}+05$ & $a$ \\
\hline 3 Wind & $\mathrm{J}$ & $7.04 \mathrm{E}+15$ & $8.44 \mathrm{E}+14$ & $1.15 \mathrm{E}+15$ & $1.59 \mathrm{E}+15$ & $3,99 \mathrm{E}+15$ & $2.47 \mathrm{E}+03$ & $a$ \\
\hline 4 Geothermal heat & $\mathrm{J}$ & $2.14 \mathrm{E}+15$ & $6.62 \mathrm{E}+14$ & $3.65 \mathrm{E}+14$ & $3.50 \mathrm{E}+14$ & $7,01 \mathrm{E}+14$ & $3.02 \mathrm{E}+04$ & $a$ \\
\hline \multicolumn{9}{|c|}{ LOCAL NON RENEWABLE RESOURCES (N) } \\
\hline 5 Sand and gravel & $\mathrm{g}$ & $1.43 \mathrm{E}+12$ & - & $6.75 \mathrm{E}+11$ & $5.61 \mathrm{E}+11$ & - & $1.68 \mathrm{E}+09$ & $a$ \\
\hline 6 Clay & $\mathrm{g}$ & $1.40 \mathrm{E}+11$ & $7.14 \mathrm{E}+10$ & $5.25 \mathrm{E}+9$ & $6.30 \mathrm{E}+10$ & - & $1.68 \mathrm{E}+09$ & $a$ \\
\hline 7 Limestone & $\mathrm{g}$ & $1.06 \mathrm{E}+12$ & $1.06 \mathrm{E}+12$ & - & - & $1.06 \mathrm{E}+12$ & $1.68 \mathrm{E}+09$ & $a$ \\
\hline 8 Loss of topsoil & $\mathrm{J}$ & $4.09 \mathrm{E}+14$ & $2.39 \mathrm{E}+14$ & $5.16 \mathrm{E}+13$ & $5.33 \mathrm{E}+13$ & $8,42 \mathrm{E}+13$ & $1.24 \mathrm{E}+05$ & $a$ \\
\hline 9 Water & $\mathrm{g}$ & $4.50 \mathrm{E}+13$ & $2.66 \mathrm{E}+13$ & $5.43 \mathrm{E}+12$ & $6.68 \mathrm{E}+12$ & $6,37 \mathrm{E}+12$ & $1.95 \mathrm{E}+06$ & $b$ \\
\hline \multicolumn{9}{|c|}{ IMPORTED ENERGY SOURCES (F1) } \\
\hline 10 Fuel & $\mathrm{J}$ & $1.54 \mathrm{E}+16$ & $8.49 \mathrm{E}+15$ & $2.41 \mathrm{E}+15$ & $2.42 \mathrm{E}+15$ & $2.08 \mathrm{E}+15$ & $1.11 \mathrm{E}+05$ & $c$ \\
\hline 11 Natural gas & $\mathrm{J}$ & $2.13 \mathrm{E}+16$ & $1.17 \mathrm{E}+16$ & $3.34 \mathrm{E}+15$ & $3.36 \mathrm{E}+15$ & $2.88 \mathrm{E}+15$ & $6.72 \mathrm{E}+04$ & $c$ \\
\hline 12 Electricity & J & $7.52 \mathrm{E}+15$ & $4.02 \mathrm{E}+15$ & $9.14 \mathrm{E}+14$ & $1.23 \mathrm{E}+15$ & $1.36 \mathrm{E}+15$ & $2.30 \mathrm{E}+05$ & $p$ \\
\hline
\end{tabular}


Table 2: $\quad$ Imported goods and materials (expressed in energy or mass units) [*See Appendix for references of transformities].

\begin{tabular}{|c|c|c|c|c|c|c|c|c|}
\hline & Unit & $\begin{array}{l}\text { Province of } \\
\text { Ancona }\end{array}$ & $\begin{array}{l}\text { Ancona-Osimo- } \\
\text { Falconara (AOF) }\end{array}$ & $\begin{array}{c}\text { Bassa Valle } \\
\text { del Misa }\end{array}$ & $\begin{array}{c}\text { Media Valle } \\
\text { dell'Esino }\end{array}$ & $\begin{array}{c}\text { Comunità } \\
\text { Montana Alta } \\
\text { Valle dell'Esino } \\
\end{array}$ & $\begin{array}{l}\text { Transformities } \\
\quad\left(\text { sej unit }{ }^{-1}\right)\end{array}$ & Ref:* \\
\hline \multicolumn{9}{|l|}{ IMPORTED GOODS (F2) } \\
\hline 13 Crops & $\mathrm{J}$ & $1.41 \mathrm{E}+16$ & $4.56 \mathrm{E}+15$ & $3.20 \mathrm{E}+15$ & $3.07 \mathrm{E}+15$ & $3.25 \mathrm{E}+15$ & $2.67 \mathrm{E}+05$ & $d$ \\
\hline 14 Legumes & $\mathrm{J}$ & $5.56 \mathrm{E}+14$ & $1.80 \mathrm{E}+14$ & $1.26 \mathrm{E}+14$ & $1.21 \mathrm{E}+14$ & $1.28 \mathrm{E}+14$ & $1.39 \mathrm{E}+05$ & $e$ \\
\hline 15 Fruits & $\mathrm{J}$ & $4.52 \mathrm{E}+12$ & $1.47 \mathrm{E}+12$ & $1.03 \mathrm{E}+12$ & $9.86 \mathrm{E}+11$ & $1.04 \mathrm{E}+12$ & $4.82 \mathrm{E}+05$ & $d$ \\
\hline 16 Filamentose vegetables & $\mathrm{J}$ & $1.33 \mathrm{E}+11$ & $4.31 \mathrm{E}+10$ & $3.02 \mathrm{E}+10$ & $2.90 \mathrm{E}+10$ & $3.07 \mathrm{E}+10$ & $3.19 \mathrm{E}+06$ & $f$ \\
\hline 17 Seeds & $\mathrm{J}$ & $1.60 \mathrm{E}+15$ & $5.18 \mathrm{E}+14$ & $3.63 \mathrm{E}+14$ & $3.48 \mathrm{E}+14$ & $3.69 \mathrm{E}+14$ & $1.33 \mathrm{E}+06$ & $d$ \\
\hline 18 Spices & $\mathrm{J}$ & $3.05 \mathrm{E}+13$ & $9.87 \mathrm{E}+12$ & $6.92 \mathrm{E}+12$ & $6.64 \mathrm{E}+12$ & $7.04 \mathrm{E}+12$ & $3.36 \mathrm{E}+05$ & $f$ \\
\hline 19 Plants and flowers & $\mathrm{g}$ & $2.17 \mathrm{E}+09$ & $7.03 \mathrm{E}+08$ & $4.93 \mathrm{E}+08$ & 4. $73 \mathrm{E}+08$ & $5.01 \mathrm{E}+08$ & $4.74 \mathrm{E}+09$ & $g$ \\
\hline 20 Products of breeding & $\mathrm{J}$ & $9.15 \mathrm{E}+13$ & $2.97 \mathrm{E}+13$ & $2.08 \mathrm{E}+13$ & $2.00 \mathrm{E}+13$ & $2.11 \mathrm{E}+13$ & $5.33 \mathrm{E}+06$ & $h$ \\
\hline 21 Products of forestry & $\mathrm{g}$ & $3.44 \mathrm{E}+09$ & $1.12 \mathrm{E}+09$ & $7.82 \mathrm{E}+08$ & $7.51 \mathrm{E}+08$ & $7.95 \mathrm{E}+08$ & $1.68 \mathrm{E}+08$ & $f$ \\
\hline 22 Prod. of fishing and hunting & $\mathrm{J}$ & $2.76 \mathrm{E}+13$ & $2.44 \mathrm{E}+13$ & $2.85 \mathrm{E}+12$ & $8.29 \mathrm{E}+10$ & $2.76 \mathrm{E}+11$ & $2.27 \mathrm{E}+08$ & $i$ \\
\hline 23 Metallic minerals & $\mathrm{g}$ & $2.92 \mathrm{E}+09$ & $1.49 \mathrm{E}+09$ & $7.91 \mathrm{E}+08$ & $1.34 \mathrm{E}+08$ & $5.00 \mathrm{E}+08$ & $1.68 \mathrm{E}+09$ & $h$ \\
\hline 24 Non metallic minerals & $\mathrm{g}$ & $3.37 \mathrm{E}+12$ & $8.77 \mathrm{E}+11$ & $1.32 \mathrm{E}+10$ & $7.87 \mathrm{E}+09$ & $9.83 \mathrm{E}+09$ & $2.76 \mathrm{E}+09$ & $j$ \\
\hline 25 Food industry & $\mathrm{J}$ & $3.68 \mathrm{E}+14$ & $1.43 \mathrm{E}+14$ & $4.50 \mathrm{E}+13$ & $1.48 \mathrm{E}+14$ & $3.27 \mathrm{E}+13$ & $5.33 \mathrm{E}+06$ & $h$ \\
\hline 26 Tobacco Industry & $\mathrm{J}$ & $3.07 \mathrm{E}+09$ & $9.96 \mathrm{E}+08$ & $6.98 \mathrm{E}+08$ & $6.70 \mathrm{E}+08$ & $7.10 \mathrm{E}+08$ & $1.76 \mathrm{E}+05$ & $h$ \\
\hline 27 Leather industry & $\mathrm{J}$ & $2.03 \mathrm{E}+12$ & $5.70 \mathrm{E}+11$ & $5.32 \mathrm{E}+11$ & $1.62 \mathrm{E}+11$ & $7.65 \mathrm{E}+11$ & $1.44 \mathrm{E}+07$ & $k$ \\
\hline 28 Textile industry & $\mathrm{J}$ & $1.00 \mathrm{E}+14$ & $3.12 \mathrm{E}+13$ & $2.88 \mathrm{E}+13$ & $2.55 \mathrm{E}+13$ & $1.48 \mathrm{E}+13$ & $6.38 \mathrm{E}+06$ & $f$ \\
\hline 29 Furniture and fixtures industry & $\mathrm{J}$ & $8.67 \mathrm{E}+13$ & $4.01 \mathrm{E}+13$ & $2.45 \mathrm{E}+13$ & $1.36 \mathrm{E}+13$ & $8.46 \mathrm{E}+12$ & $6.38 \mathrm{E}+06$ & $f$ \\
\hline 30 Wood industry & $\mathrm{g}$ & $1.42 \mathrm{E}+11$ & $9.18 \mathrm{E}+10$ & $2.47 \mathrm{E}+10$ & $1.37 \mathrm{E}+10$ & $1.20 \mathrm{E}+10$ & $3.90 \mathrm{E}+09$ & $l$ \\
\hline 31 Paper industry & $\mathrm{J}$ & $7.83 \mathrm{E}+15$ & $1.18 \mathrm{E}+15$ & $1.76 \mathrm{E}+15$ & 4. $09 \mathrm{E}+14$ & $4.48 \mathrm{E}+15$ & $3.61 \mathrm{E}+05$ & $f$ \\
\hline 32 Graphic industry & $\mathrm{J}$ & $1.25 \mathrm{E}+12$ & $8.74 \mathrm{E}+11$ & $9.54 \mathrm{E}+10$ & $1.38 \mathrm{E}+11$ & $1.43 \mathrm{E}+11$ & $3.61 \mathrm{E}+05$ & $f$ \\
\hline 33 Metallurgical industry & $\mathrm{g}$ & $2.85 \mathrm{E}+11$ & $1.46 \mathrm{E}+11$ & $7.72 \mathrm{E}+10$ & $1.31 \mathrm{E}+10$ & $4.88 \mathrm{E}+10$ & $1.13 \mathrm{E}+10$ & $f$ \\
\hline 34 Mechanic industry & $\mathrm{g}$ & $1.20 \mathrm{E}+11$ & $4.91 \mathrm{E}+10$ & $1.05 \mathrm{E}+10$ & $2.68 \mathrm{E}+10$ & $3.40 \mathrm{E}+10$ & $2.10 \mathrm{E}+10$ & $m$ \\
\hline 35 Industry of minerals & $\mathrm{g}$ & $8.72 \mathrm{E}+10$ & $2.27 \mathrm{E}+10$ & $2.76 \mathrm{E}+10$ & $1.64 \mathrm{E}+10$ & $2.05 \mathrm{E}+10$ & $3.09 \mathrm{E}+09$ & $n$ \\
\hline 36 Chemical industry & $\mathrm{g}$ & $4.46 \mathrm{E}+11$ & $3.55 \mathrm{E}+11$ & $2.95 \mathrm{E}+10$ & $2.53 \mathrm{E}+10$ & $2.01 \mathrm{E}+10$ & $6.38 \mathrm{E}+08$ & $o$ \\
\hline 37 Industry of rubber & $\mathrm{g}$ & $1.15 \mathrm{E}+10$ & $6.24 \mathrm{E}+09$ & $1.45 \mathrm{E}+09$ & $2.44 \mathrm{E}+09$ & $1.39 \mathrm{E}+09$ & $7.22 \mathrm{E}+09$ & $f$ \\
\hline 38 Other industries & g & $1.42 \mathrm{E}+10$ & $9.40 \mathrm{E}+09$ & $1.93 \mathrm{E}+09$ & $2.31 \mathrm{E}+09$ & $5.99 \mathrm{E}+08$ & $5.81 \mathrm{E}+09$ & $h$ \\
\hline
\end{tabular}

Table 3: $\quad$ Summary of general data. Emergy flows and emergy indices.

\begin{tabular}{|c|c|c|c|c|c|c|c|}
\hline & & & $\begin{array}{c}\text { Province of } \\
\text { Ancona }\end{array}$ & $\begin{array}{c}\text { Ancona-Osimo- } \\
\text { Falconara } \\
\text { (AOF) }\end{array}$ & $\begin{array}{c}\text { Bassa Valle } \\
\text { del Misa }\end{array}$ & $\begin{array}{l}\text { Media Valle } \\
\text { dell'Esino }\end{array}$ & $\begin{array}{c}\text { Comunità } \\
\text { Montana Alta } \\
\text { Valle dell'Esino } \\
\end{array}$ \\
\hline & Unit & Expression & & & & & \\
\hline \multicolumn{8}{|l|}{ GENERAL DATA } \\
\hline Area & $\mathrm{km}^{2}$ & & $1,940.00$ & 552.05 & 330.39 & 317.2 & 740.52 \\
\hline Population & inhabitants & & 444.056 & 244.692 & 69.511 & 69.917 & 59.936 \\
\hline Population Density & inhab. $\mathrm{km}^{-2}$ & & 229 & 443 & 210 & 220 & 81 \\
\hline \multicolumn{8}{|c|}{ EMERGY FLOWS (expressed in $10^{20}$ sej yr $\mathrm{yr}^{-1}$ ) } \\
\hline Local renewable emergy & sej $\mathrm{yr}^{-1}$ & $\mathrm{R}$ & 3.49 & 0.96 & 0.59 & 0.56 & 1.47 \\
\hline Local non renew. emergy & sej $\mathrm{yr}^{-1}$ & $\mathrm{~N}$ & 45.61 & 2.01 & 11.59 & 10.67 & 21.36 \\
\hline Emergy of imported energy & sej $\mathrm{yr}^{-1}$ & F1 & 31.61 & 17.13 & 7.02 & 7.77 & 7.36 \\
\hline Emergy of imported goods & sej $\mathrm{yr}^{-1}$ & $\mathrm{~F} 2$ & 269.03 & 128.72 & 46.93 & 34.99 & 49.42 \\
\hline Total Emergy & sej $\mathrm{yr}^{-1}$ & EM & 349.75 & 148.83 & 66.13 & 54.00 & 79.60 \\
\hline \multicolumn{8}{|l|}{ EMERGY INDICES } \\
\hline Empower Density & $10^{13}$ sej $\mathrm{m}^{-2} \mathrm{yr}^{-1}$ & $\mathrm{EM} /$ area & 1.80 & 2.70 & 2.00 & 1.70 & 1.07 \\
\hline Emergy per Person & $10^{16}$ sej inhab $^{-1} \mathrm{yr}^{-1}$ & EM/inhabitants & 7.88 & 6.08 & 9.51 & 7.72 & 1.33 \\
\hline Emergy Investment Ratio & & $\mathrm{F} /(\mathrm{N}+\mathrm{R})$ & 6.12 & 49.09 & 4.43 & 3.81 & 2.49 \\
\hline Environmental Loading Ratio & & $(N+F) / R$ & 99.21 & 154.55 & 110.42 & 95.09 & 53.29 \\
\hline Emergy Yield Ratio & & $\mathrm{EM} / \mathrm{F}$ & 1.16 & 1.02 & 1.23 & 1.26 & 1.40 \\
\hline
\end{tabular}


The emergy yield ratio (EYR) is 1.16. It highlights that the system depends from external non renewable resources. The more the EYR value is close to 1, the more the system is based on resources from outside the system and the contribution of the environment is negligible. The EIR value of 6.12 , due to the high contribution of imported goods and services (F), confirms a high dependence on external flows of resources.

The ELR shows a high use of non renewable resources $(\mathrm{F}+\mathrm{N})$ with respect to renewables (R). The ELR value (99.20) is consistent with the presence of important industrial activities and high population density. This indicator can be read as the contribution of the local system to global non-sustainability because of the high use of non renewable resources.

These results are supported by the analysis of the areal empower density, $1.80 \times 10^{13}$ sej $\mathrm{m}^{-2} \mathrm{yr}^{-1}$, that could be considered as a measure of the anthropic pressure on the regional system. In this case, space can be a limiting factor for future development due to high concentration of resources in the area.

Emergy Evaluation has been also performed for the four districts, in order to provide specific information on different subsystems.

The AOF district uses $43 \%$ of the total emergy in connection with $55 \%$ of the total population and about $50 \%$ of employments in industries. Also the emergy indices have higher values in this district that plays a critical role within the region in terms of environmental resource use.

The other $57 \%$ of emergy flow is almost homogeneously distributed among the other three districts. In general, in the four districts the contribution of local renewable resources is low and the contribution of local non renewables increases from east to west, from the coast to the inland. The inland district Comunità Montana Alta Valle dell'Esino is the one with the lowest impacts.

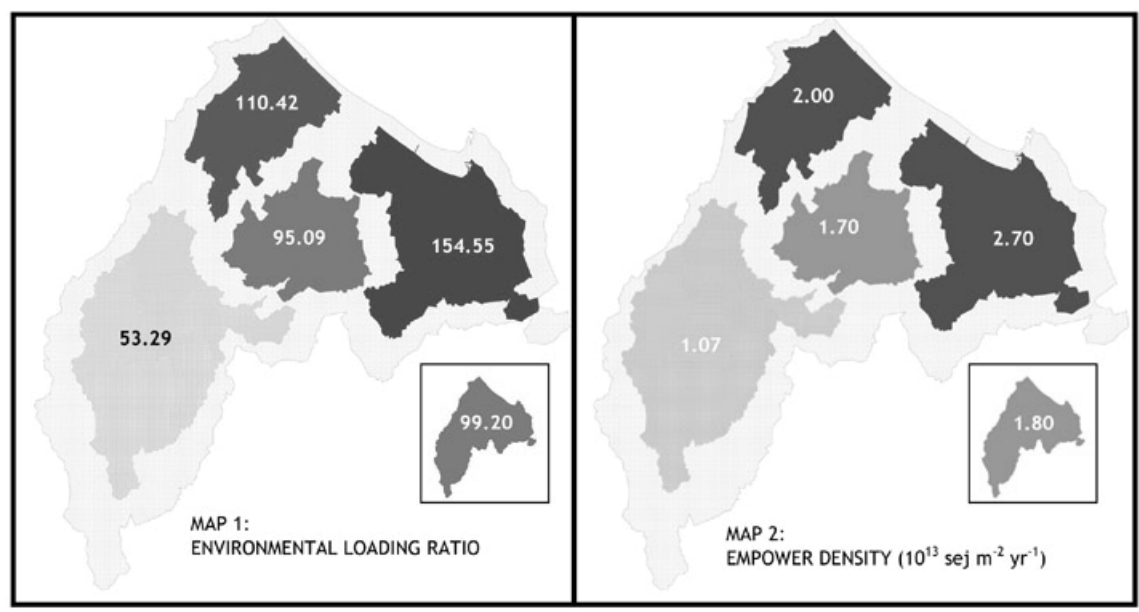

Figure 3: $\quad$ Maps of ELR (left) and ED (right) for the Province of Ancona and its four districts. 
High values of ELR and ED indicate a high anthropic pressure due to a high demographic density and an intensive presence of industrial activities (Fig. 3). Resources imported from outside are more concentrated in the areas where the main industries and cities are located. Cities are dynamic systems able to produce welfare and services, labour and capital, interaction factors and communicability, opportunities to create and diffuse information, culture and news. This kind of production justifies the presence of intense flows of matter and energy in spite of high values of environmental loading ratio compared with the other parts of the region. In a sense, territories characterized by low environmental pressure should be preserved as a counterpart of high anthropized areas.

In the Province of Ancona, the region can be ideally classified into two macro-areas according to the quantities of energy and matter that supply activities and human settlements: the urban and the natural (rural) areas, which correspond to the coastal and the mountain system, respectively. Practices of territorial planning in this province should follow two different strategies to drive local development and environmental management, according to this classification.

The first strategy, to be applied in urban areas, is based on the idea of an urban development able to rationalize the use of energy and matter. Sustainability requires one to leave gradually and clearly the practices based on the aggrandizement of cities. The empowerment density just says that space is limited and it is no more sufficient to sustain the pressure of cities. Considering the relationship existing between urban areas and natural areas, a sustainable planning of urban areas has to figure out new organizational configurations coherent with their local contest and able to decrease, for example, energy consumptions in buildings.

The second strategy, to be applied in natural areas, is based on the idea of a rural development, strikingly at variance with those activities that intensively use resources. This should imply the rational exploitation of renewable resources and direct choices towards activities not based on economic growth or urban sprawl. Activities based on local products from both agriculture and craft, on traditional gastronomy and on the preservation of typical goods are consistent with this idea of local development. Sustainable tourism and agriculture have to be promoted as well as diffuse services in order to facilitate life in villages and to stop the exodus of people towards the cities along the coast. An energy program has to act for reducing consumptions in the small centres and, where it is possible, developing an energy production by small hydroelectric, aeolian or photovoltaic plants, obviously taking into account their impacts on the environment.

From a sustainable viewpoint, territorial planning must relate as much as possible its strategic choices to the local vocations of various territorial areas. Choices and actions have to work according to a common idea of development. The role of the environmental platform, as resource reservoir or wastes and emission absorber, must be enhanced and promoted. 


\section{Conclusion}

A sustainability analysis based on Emergy Evaluation has been performed for a territorial system, the Province of Ancona (Italy). The results describe a variegated system where a high population density and the manufacturing activities produce a relevant impact on the territory. This corresponds to a high emergy flow that supply the region $\left(3.50 \times 10^{22}\right.$ sej $\left.\mathrm{yr}^{-1}\right)$, mainly composed by non-renewable imported resources $(\mathrm{F}=86 \%$ of total emergy). This is also highlighted by high values of indicators of environmental stress, such as the Environmental Loading Ratio and the Empower Density. Emergy Analysis also shows that the Province is largely dependent on imported and non renewable resources with a low exploitation of local renewables (as indicated also by the Emergy Investment Ratio).

The emergy evaluation of the province of Ancona provided powerful information for territorial planning. In particular, the analysis of subsystems indicated different strategies to direct future development which preserve the diversities and heterogeneities inside the region against the negative influence of economic growth and globalisation. The key points are: a) to emphasize natural capital; b) to control the availability and the renewability of resources and the state of the environment; c) to evaluate the degree of exploitation of natural resources; d) to systematically collect statistical data about land, activities and environment; e) to enhance the diversities of geomorphology, society, economy and to consider them as an opportunity for a future sustainable development.

\section{Appendix: references for transformities}

(a) Odum, H.T., Brown, M.T. and Williams, S.B. (2000). Handbook of emergy evaluation: a compendium of data for emergy computation issued in a series of folios. Folio \#1 - Introduction and Global Budget. Center for Environmental Policy, University of Florida, Gainesville, FL.

(b) Tiezzi, E. (Ed.) (2001). Implementazione di un sistema di contabilità ambientale su scala provinciale e intercomunale. Experimental project sponsored by Italian Minister for the Environment. University of Siena and Province of Bologna, Bologna, Italy. Available at http://www.provincia.bologna.it/ambiente/pdf_pubblicazioni/contabilita_am bientale.pdf.

(c) Bastianoni, S., Campbell, D., Susani, L. and Tiezzi, E. (2005). The solar transformity of oil and petroleum natural gas. Ecological Modelling, 186, 212-220.

(d) Ulgiati, S., Odum, H.T., Bastianoni, S. (1993). Emergy analysis of Italian agricultural system: the role of energy quality and environmental inputs. (Eds.) Bonati L, Cosentino U, Lasagni M, Moro G, Pitea D and Schiraldi A. Proc. 2nd Int. workshop - Trends in ecological physical chemistry. Elsevier, Amsterdam, The Netherlands, 187-215.

(e) Bastianoni, S., Brown, M.T., Marchettini, N. and Ulgiati, S. (1994). Assessing energy quality, process efficiency and environmental loading in 
biofuels production from biomass. (Eds.) Chartier Ph, Beenackers A A C, and Grassi G. Proc. 8th European Biomass Conference - Biomass for energy environment, agriculture and industry. Pergamon, Oxford, 2300-2312.

(f) Brown, M.T. and Arding, J.E. (1991). Transformity Working Paper. Center for Wetlands, University of Florida, Gainesville, FL.

(g) Tiezzi, E., (Ed.) (2000a). Analisi di sostenibilità ambientale del Comune di Pescia. Unpublished report, Siena, Italy.

(h) Ulgiati, S., Odum, H.T., Bastianoni, S. (1994). Emergy use, environmental loading and sustainability. An emergy analysis of Italy. Ecological Modelling, 73, 215-268.

(i) Tiezzi, E., (Ed.) (2000b). Studio per un progetto di valutazione di scenari per uno sviluppo sostenibile della Laguna di Venezia, Unpublished report, Siena, Italy.

(j) Odum, H. T. (1992). Emergy and public policy (part I-II).Gainesville, FL: Environmental Engineering Sciences, University of Florida.

(k) Odum, H.T. and Odum, E.C. (1987). Ecology and Economy. Emergy Analysis and Public Policy in Texas. Lyndon B Johnson School of Public Affairs, Policy Research Project Report n. 78. Austin, TX.

(1) Odum, H.T. and Arding, J.E. (1991). Emergy analysis of shrimp marine culture in Ecuador. Department of Environmental Engineering Sciences, University of Florida, Working paper prepared for Coastal Resources Center, University of Rhode Island, Narragansett, RI.

(m) Odum, H.T. and Odum, E.C. (1983). Energy Analysis Overview of Nations. WP-83-82, International Institute for Applied Systems Analysis, Laxenburg, Austria.

(n) Bjorklund, J., Geber, U. and Rydberg, T. (2000). Emergy analysis of municipal wastewater treatment and generation of electricity by digestion of sewage sludge; a Swedish case study. Resources Conservation \& Recycling 31 (4), 293-316.

(o) Odum, H. T. (1996). Environmental accounting: Emergy and environmental decision making. New York, US: Wiley.

(p) Bastianoni, S., Marchettini, N., Principi, I. and Tiezzi, E. (2001). Sviluppo di un modello di analisi emergetica per il sistema elettrico nazionale. Unpublished report, Siena, Italy.

\section{References}

[1] For an overview of sustainability indicators and their application at the territorial level, see the Journal of Environmental Management, Volume 86, Issue 2, January 2008, pp. 329-426, Special Issue on "SPIn-Eco: Sustainability of the Siena Province through Ecodynamic Indicators".

[2] World Resource Institute, Wuppertal Institute, Netherlands Ministry of Housing, Spatial Planning and Environment, National Institute for Environmental Studies "Resources Flows: the material basis of industrial economies", 1997, Washinghton D.C., USA. 
[3] Hille, J. (1998). The concept of environmental space. Implication for policies, environmental reporting and assessment, EEA.

[4] Wall, G. (1990). Exergy conversion in the Japanese society. Energy, 15, 435-444.

[5] Sciubba, E. (1995). Modelling the energetic and exergetic selfsustainability of societies with different structure. J. Eng. Res. Techn., 117(6), 75-86.

[6] Wackernagel, M., Rees, W. (1996). The Ecological Footprint: reducing human impact on the Earth, New Society, Gabriola Island, BC, Canada.

[7] Wackernagel, M., Onisto, L., Bello, P., Callejas, L. A., López, F. I., García, J., Guerriero, A., Guerrero, S. National natural capital accounting with the ecological footprint concept. Ecol. Econ. (29)3, 375-390.

[8] Odum, H.T. (1988). Science, 242, 1132-1139.

[9] Odum, H.T. (1996). Environmental Accounting: Emergy and Environmental Decision Making", John Wiley and Sons, New York (USA).

[10] Some historical backgrounds of the concept of emergy can be found in Brown, M., Ulgiati, S. (2004). Energy quality, emergy, and transformity: H.T. Odum's contributions to quantifying and understanding systems. Ecological Modelling, 178 (1-2), 201-213.

[11] Ulgiati, S., Brown, M.T., Bastianoni, S., Marchettini, N. (1995). Emergy based indices and ratios to evaluate the sustainable use of resources. Ecological Engineering, 5(4), 519-531.

[12] Campbell, D.E. (1998) Emergy analysis of human carrying capacity and regional sustainability: an example using the state of Maine. Environmental Monitoring and Assessment, 51(1-2), 532-569.

[13] Pulselli, R.M., Rustici, M., Marchettini, N. (2007). An integrated framework for regional studies: emergy based spatial analysis of the Province of Cagliari. Environmental Monitoring and Assessment, 133 (1-3), 1-13.

[14] Higgins, J.B. (2003). Emergy analysis of the Oak Openings region. Ecological Engineering, 21(1), 75-109. 